\title{
Equations for Estimating Bark Volume and Thickness of Commercial Trees in British Columbia
}

\author{
by \\ A. Kozak ${ }^{1}$ and R. C. Yang ${ }^{2}$
}

\begin{abstract}
Volume and thickness of bark were studied for 32 species groups of British Columbia. Over 32,000 trees constituted the data base to derive bark volume equations. Because of its simplicity and good predictive power, the equation of $V_{b}=a^{\prime} H^{b}{ }^{b} D B H^{c} B T^{d}$ is recom. mended for bark volume prediction. The possibility to develop bark taper equations and to estimate bark thickness at any given height above breast height were also investigated.
\end{abstract}

\section{Résumé}

Le volume et l'épaisseur de l'écorce furent étudiés pour 32 espèces de la Colombie Britannique. Plus de 32,000 arbres ont servi à continuer les données qui ont permis de construire des équations volume-écorce. À cause de sa simplicité et sa capacité de prédiction, l'équation $\mathrm{Vb}=\mathrm{a}^{\prime} \mathrm{DBH}^{\mathrm{c} B T^{\mathrm{d}}}$ est recommandée. $\mathrm{La}$ possibilité de développer des équations sur le défilement de l'écorce et d'estimer l'épaisseur de l'écorce à quelque niveau de la tige au dessus du DHP a été étudiée.

\section{Introduction}

Currently unused residues from timber harvesting and processing represent a potential source of energy which could be tapped profitably. Bark has received much more emphasis than other residues because of its abundance in quantity and its high heating values (Schneider, 1977). A process to pelletize Douglas-fir bark has been developed, and bark pellets, which are a high energy fuel, have been commercially produced (Blackman, 1978).

Bark studies have been predominantly on the determination of bark thickness in relation to tree diameter (MacKinney 1934; Hale 1955; Smith and Kozak 1971; Lange 1971; Fedvccia and Mann 1976). Some efforts have been made to estimate bark thickness from tree parameters (Smith and Kosak 1967; Brickell 1970), but few attempts have been made to estimate bark volume. With advances in forest products technology and the increasing demand for alternative sources of energy, the need to estimate the volume of bark which is potentially available for utilization becomes critical. This study investigated bark volume equations for commercial trees in British Columbia and developed a taper system to predict bark thickness on the tree bole at any specific heights above ground.

\section{Equations for Estimating Bark Thickness and Volume}

Meyer (1946) developed mathematical equations for estimating bark thickness and volume

[1] $\quad B=D / 2(1 \cdot k)$

[2] $V_{b}=V\left(1-k^{2}\right)$

where $B$ is bark thickness, $V_{b}$ is bark volume, $D$ is usually

\footnotetext{
1 Professor and Associate Dean, Faculty of Forestry, THe University of British Columbia, Vancouver, BC V6T 1W5. Financial support of the National Research Council of Canada is gratefully acknowledged.

${ }^{2}$ Former Research Associate Faculty of Forestry, UBC. Now Project Leader, Regeneration Survey, American Can of Canada Ltd., Marathon, Ontario, POT 2EO.
}

diameter at breast height outside bark (DBHOB), but could be diameter outside bark (DOB) at any point on the tree; $V$ is stem volume including bark and $\mathrm{k}$ is the regression coefficient for the relationship of diameter inside bark (DIB, d) to DOB. Meyer plotted DIB as a function of DOB and obtained a constant ratio with a straight line passing through the origin. Thus, the constant $\mathrm{k}$ is determined by the equation

$$
k=\frac{\Sigma d}{\Sigma D}=\frac{\Sigma D-\Sigma D B T}{\Sigma D}
$$

where DBT is double bark thickness.

Stayton and Hoffman (1970) modified Meyer's equations by use of different $k$ and $D$ values to be more accurate for estimating average bark thickness and bark volume for sugar maple (Acer saccharum Marsh). However, as admitted by Meyer, the change of the form in the surface of the bark, which often occurs when a tree reaches a diameter of about 5 to 10 inches ( 12 to $25 \mathrm{~cm}$ ), may make it difficult to represent the relationship between bark thickness and diameter by a single straight line over the entire range of diameters. Therefore, to estimate accurate bark volume for trees in wide diameter ranges, it is necessary to include some size variables such as $\mathrm{DBH}$, height $(\mathrm{HT})$, bark thickness (expressed as double bark thickness at breast height, DBTBH) and others. Indeed, in his recent study of mathematical models for determining the bark volume of spruce in relation to certain size variables, Dimitrov (1976) found the best models were three non-linear functions which expressed bark volume as a function of $\mathrm{DBH}$, height, volume, age and site class.

\section{Data Base and Methods}

The stem analysis data for this study were collected by the British Columbia Forest Service Inventory Division. Over 32,000 trees, which constitute the data base for deriving logarithmic volume equations and for many related studies, were used. The data base has been described by Demaerschalk and Kozak (1977) in their study for tree profile systems. Briefly, these trees were stratified into 32 groups according to species, maturity, and region. For each tree, measurements were made for diameters to the nearest 0.1 in $(0.254 \mathrm{~cm})$ inside and outside bark at $1,1.5,2$, and $4.5 \mathrm{ft}(30,45,60$ and $137 \mathrm{~cm})$ and at each 10th of the height above breast height. Total height was recorded to the nearest $0.1 \mathrm{ft}$.

Original measurements recorded in Imperial units were converted to metric units; diameters at $1.3 \mathrm{~m}$ for each tree were determined by using a non-linear function developed by Demaerschalk and Kozak (1977). Bark volume for each section was computed as the difference between volumes excluding and including bark; the Smalian formula was used to compute the sectional volumes. Table 4 contains some general descriptions of the data base.

\section{Logarithmic Bark Volume Equations}

A total of 34 regression equations with bark volume or logarithmic bark volume as a dependent variable and DBH, $\mathrm{HT}$, DBTBH and their logarithmic transformations as independent variables were first fitted to 12 species groups to 
evaluate bark volume data. The five best equations were chosen based on the magnitude of standard error of estimate $\left(S_{E}\right)$ for subsequent tests for the rest of the data. Among the 34 tested equations, those with logarithmic transformation of the dependent variable had consistently better standard errors of estimate than equations without transformation. The five most promising bark volume equations are as follow:

[4] $\log \mathrm{V}_{\mathrm{b}}=a+b \log \mathrm{HT}+\mathrm{c} \log \mathrm{DBH}+\mathrm{d} \log \mathrm{BT}$

[5] $\log \mathrm{V}_{\mathrm{b}}=a+b \log \mathrm{HT}+\mathrm{c}$ DBH $+d \log \mathrm{DBH}+\mathrm{e} \log \mathrm{BT}$

[6] $\log \mathrm{V}_{\mathrm{b}}=a+b \log \mathrm{HT}+c \log \mathrm{DBH}+d \mathrm{BT}+\mathrm{e} \log \mathrm{BT}$

[7] $\log V_{b}=a+b \log H T+c \log \mathrm{DBH}+d \mathrm{DBH}^{2}+e \log \mathrm{BT}$

[8] $\log \mathrm{V}_{b}=a+b \log \mathrm{HT}+c \log \mathrm{DBH}+d B T^{2}+e \log \mathrm{BT}$

where $V_{b}$ is bark volume, BT is double bark thickness at breast height, and a, b, c, d, and e are regression coefficients.

It can be noted in Table 1 that no equation is consistantly better than the others in all 12 species groups tested. In addition, differences in precision in terms of the standard error of estimate among functions are practically negligible. In order to select a function which reliably estimates the bark volume for trees in various maturity stages and inventory zones in BC, the five chosen equations were then fitted to all 32 species groups and a ranking system was used in the selection. For a species group, the rank $1,2, \ldots$ or 5 was assigned to a function according to the magnitude of $\mathrm{SE}_{\mathrm{E}}$ of the function fitted to the species group, a function with the smallest $\mathrm{SE}_{\mathrm{E}}$ within the group being assigned to 1 and so on. Table 2 presents the relative merits of the five chosen functions in 32 species groups as indicated by $\mathrm{SE}_{\mathrm{E}}$.

With the aid of Table 2, it is possible to single out Equation [7] as the best estimator for bark volume for trees in BC. The standard errors of estimate of Equation [7] range from $0.0035 \mathrm{~m}^{3}$ for maple with 139 trees to $0.6974 \mathrm{~m}^{3}$ for coastal mature Douglas-fir with 603 trees tested. In view of the small $\mathrm{SE}_{\mathrm{E}}$, it can be concluded that the estimator is very precise.

The accuracy of an estimating system also is important; it is measured by the magnitude of bias. Bias was computed as the average of the differences between observations and predictions of the system. The bias of Equation [7] ranges from $0.0001 \mathrm{~m}^{3}$ for yellow cedar with 296 sample trees to $0.035 \mathrm{~m}^{3}$ for the coast mature Douglas-fir with 603 trees. The estimator is very accurate as evidenced by the small magnitude of bias. However, as indicated in Table 3 , the bias increases with the increase of $\mathrm{DBH}$. In addition, the logarithmic bark volume equation underestimates the true value.

For practical purposes, however, Equation [4] is simpler than Equation [7], and could be expressed as

[9] $\mathrm{V}_{\mathrm{b}}=\mathrm{a}^{1} \mathrm{HT}^{\mathrm{b}} \mathrm{DB} \mathrm{H}^{\mathrm{c}} \mathrm{BT}^{\mathrm{d}}$ where $\mathrm{a}^{1}=$ anti-log a which is very similar to the logarithmic volume equations presently used in British Columbia. The precision of this equation is not significantly different from Equation [7] (Table 1). Therefore, it is suggested that Equation [4] should be accepted for practical use to estimate bark volume from $\mathrm{DBH}$, height and double bark thickness at breast height. Table 4 summarizes the regression coefficients and the coefficients of determinations for the 32 species groups ${ }^{3}$.

\section{Meyer's k Values for BC Trees}

Meyer's method to estimate bark volume has been tested by several investigators with satisfactory results. However, when the method was examined with the data of 32 species groups the estimator was found to be highly variable and biased. Table 4 presents the $\mathrm{k}$ values (computed from Equation [3]).

3 The coefficients of the other equations are available on request.

Table 1. Comparison of standard error of estimates ${ }^{1}$ of five bark volume equations for some selected species group.

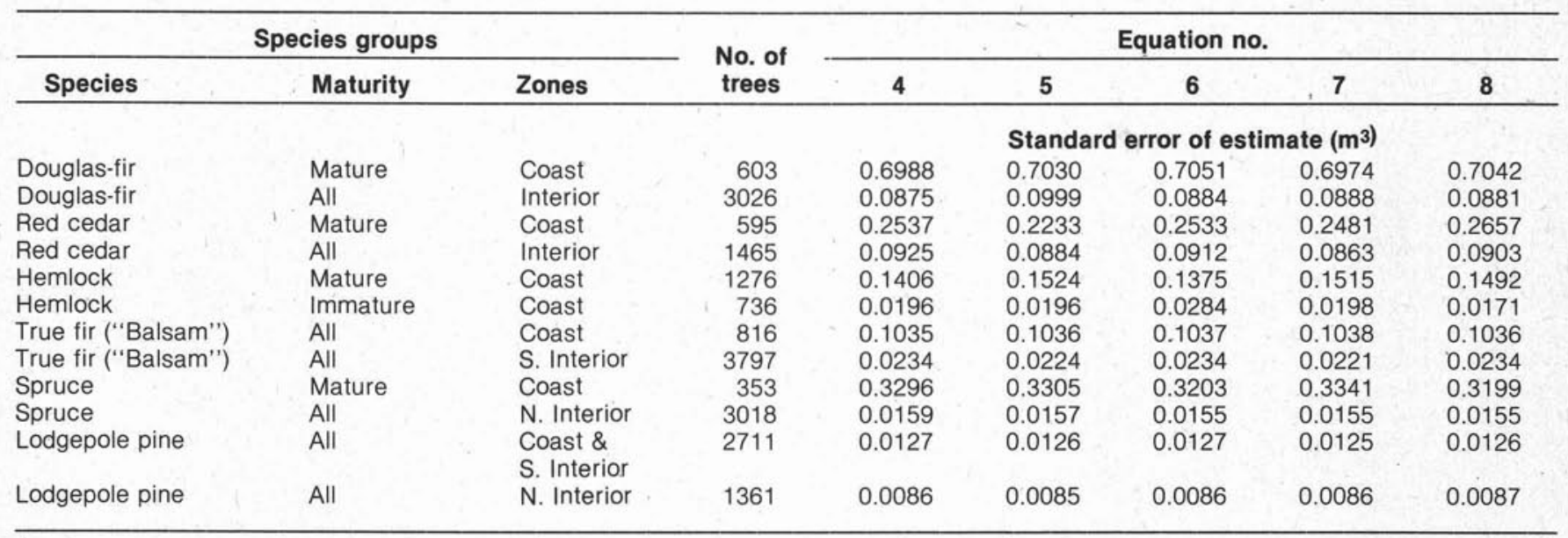

1 Based on actual $\left(\mathrm{V}_{\mathrm{b}_{i}}\right)$ and back transformed $\left(\hat{\mathrm{V}}_{\mathrm{b}_{\mathrm{i}}}\right)$ bark volumes, such as:

$S E_{E}=\sqrt{i \stackrel{\sum^{n}}{=}{ }^{(}\left(V_{b_{i}} \cdot \hat{V}_{b_{i}}\right)^{2}}$ residual variance. 
Table 2. Ranks of $S E_{E}$ for five bark volume functions fitted to 32 species groups in BC from low (1) to high (5).

\begin{tabular}{crrrrr} 
& \multicolumn{5}{c}{ Number of species groups ranked as } \\
Function & $\mathbf{1}$ & $\mathbf{2}$ & $\mathbf{3}$ & $\mathbf{4}$ & $\mathbf{5}$ \\
\hline 4 & 6 & 5 & 5 & 10 & 6 \\
5 & 8 & 12 & 4 & 4 & 4 \\
6 & 4 & 4 & 10 & 7 & 7 \\
7 & 12 & 8 & 4 & 4 & 4 \\
8 & 2 & 5 & 12 & 7 & 6 \\
\hline
\end{tabular}

The $\mathrm{SE}_{\mathrm{E}}$ of the Meyer's estimating system ranges from $0.0044 \mathrm{~m}^{3}$ for maple to $0.8047 \mathrm{~m}^{3}$ for coastal mature Douglas-fir while bias varies from $0.001 \mathrm{~m}^{3}$ to $-2.510 \mathrm{~m}^{3}$. The $\mathrm{SE}_{\mathrm{E}}$ increases with the increase of tree maturity and therefore $\mathrm{DBH}$.
The Meyer's method was designed for trees of small diameter; for larger trees the system is inapplicable. However, if the $k$ values were calculated based on a fairly large number of tree sections (each sampled tree was cut into more than 11 sections), a reliable average double bark thickness of each species group could be obtained readily from the value by the following formula:

$$
\text { [10] DBT } \%=(1-k) 100
$$

The percentage of bark thickness varies not only from species to species but also inventory zone to inventory zone. As implicitly indicated in Table 4, the thick-bark species are Douglas-fir, western larch, and yellow pine while thin-barked species are lodgepole pine, spruce and yellow cedar. The bark of larch (tamarack) grown in the Northern Interior is thinner than that grown on the Coast and in the Southern Interior. The same is true for lodgepole pine. On the other hand bark of western red cedar and hemlock grown in the Interior is relatively thicker than that grown on the Coast.

Table 3. Bias of the bark volume equation by DBH classes

\begin{tabular}{|c|c|c|c|c|c|c|c|c|c|c|}
\hline Douglas-fir & $\begin{array}{l}\text { DBH class, cm } \\
\text { \# Trees } \\
\text { Bias, } \mathrm{m}^{3}\end{array}$ & $\begin{array}{c}10-31 \\
45 \\
0.0002\end{array}$ & $\begin{array}{c}32 \cdot 52 \\
136 \\
0.0019\end{array}$ & $\begin{array}{c}53-73 \\
174 \\
0.0181\end{array}$ & $\begin{array}{c}74-94 \\
105 \\
0.0859\end{array}$ & $\begin{array}{c}95-115 \\
67 \\
0.0259\end{array}$ & $\begin{array}{c}116-136 \\
30 \\
0.2873\end{array}$ & $\begin{array}{c}137-157 \\
25 \\
0.1599\end{array}$ & $\begin{array}{c}158-178 \\
14 \\
0.9514\end{array}$ & $\begin{array}{c}179 \cdot 220 \\
7 \\
0.2544\end{array}$ \\
\hline
\end{tabular}

Table 4: Bark volume, DBH, bark thickness, regression coefficients (a,b,c,d and e) for estimation of bark volume by Equation [4] and Meyer's $k$ values for the 32 species groups studied.

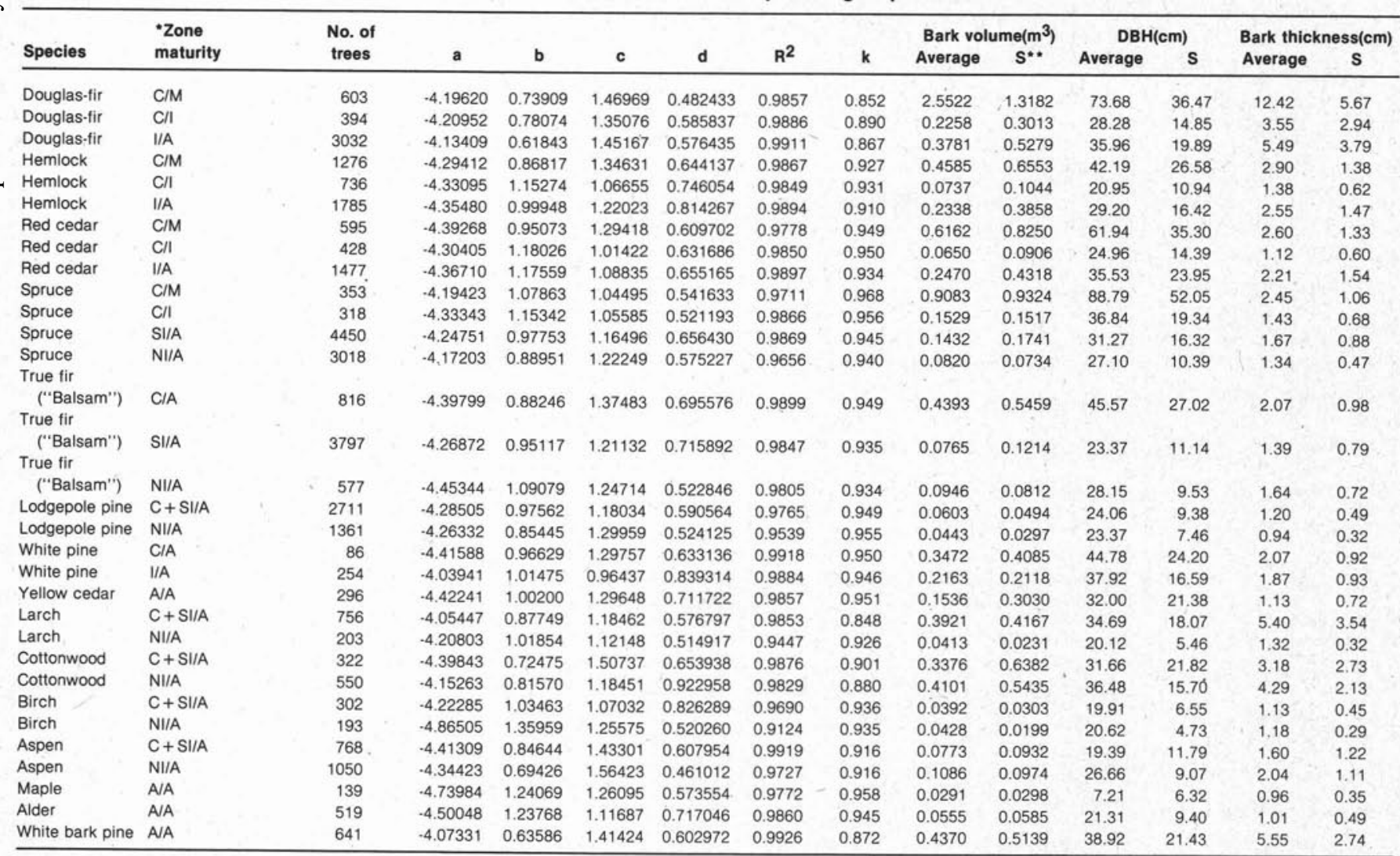

$R^{2}=$ Coefficient of determination for Equation [4]

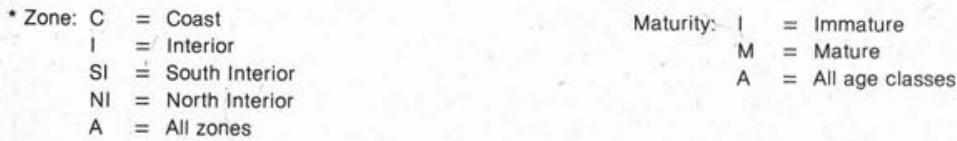


Table 5. Standard error of estimate and bias* for estimation of bark thickness at various heights.

\begin{tabular}{|c|c|c|c|c|c|c|c|c|c|c|c|c|c|}
\hline \multirow[b]{2}{*}{ Species } & \multirow[b]{2}{*}{ Maturity } & \multirow[b]{2}{*}{ Zone } & \multirow{2}{*}{$\begin{array}{l}\mathrm{SE}_{\mathrm{E}} \\
\mathrm{cm}\end{array}$} & \multicolumn{2}{|c|}{ (1) } & \multicolumn{3}{|c|}{ Average bias of Bark } & \multicolumn{2}{|c|}{ Thickness of } & \multicolumn{3}{|c|}{ (1) } \\
\hline & & & & $0.1 \mathrm{HT}$ & $0.2 \mathrm{HT}$ & $0.3 \mathrm{HT}$ & $0.4 \mathrm{HT}$ & $0.5 \mathrm{HT}$ & $0.6 \mathrm{HT}$ & $0.7 \mathrm{HT}$ & $0.8 \mathrm{HT}$ & $0.9 \mathrm{HT}$ & $1.0 \mathrm{HT}$ \\
\hline Yellow cedar & All & All & 0.609 & 0.001 & 0.074 & 0.087 & 0.127 & 0.128 & 0.183 & 0.127 & 0.046 & 0.006 & 0.000 \\
\hline Yellow pine & All & All & 0.756 & 0.000 & -0.206 & 0.158 & -0.039 & 0.079 & 0.229 & 0.261 & 0.221 & 0.054 & 0.000 \\
\hline Cottonwood & All & $\begin{array}{l}\text { Coast }+ \\
\text { S. Interior }\end{array}$ & 0.675 & 0.001 & -0.076 & -0.041 & 0.022 & 0.076 & 0.110 & 0.069 & -0.060 & -0.062 & 0.000 \\
\hline Alder & All & All & 0.185 & 0.000 & -0.015 & -0.000 & 0.004 & 0.009 & 0.025 & 0.029 & 0.026 & 0.008 & 0.000 \\
\hline Douglas-fir & Mature & Coast & 1.508 & 0.000 & -0.464 & -0.419 & -0.134 & 0.117 & 0.326 & 0.400 & 0.327 & 0.111 & -0.003 \\
\hline Douglas-fir & Immature & Coast & 0.468 & 0.000 & -0.086 & -0.061 & 0.012 & 0.060 & 0.097 & 0.086 & 0.029 & -0.015 & 0.000 \\
\hline
\end{tabular}

* Positive bias indicates underestimation and negative bias indicates overestimation.

$\mathrm{SE}_{\mathrm{E}}=$ Standard error of estimate.

$\mathrm{HT}=$ Total height.

\section{Bark Taper Equation}

Bark thickness at a specific tree height is often needed when appraising timber. An unsuccessful attempt was made by Stayton and Hoffman (1970) to develop accurate equations that predict bark thickness at a specific tree height for sugar maple. As described in previous sections, bark thickness at 1 foot, 4.5 feet, and tenths of tree height above breast height had been measured in this study, therefore, these measurements facilitate the development of bark taper equations. For many function forms, linear as well as non-linear techniques, have been tried. It was found that a non-linear function used by Demaerschalk and Kozak (1977) to describe upper bole profiles, fits satisfactorily the bark thickness data from the first tenth of height above breast height to the top of tree. The function is

$$
\text { [11] } B T=\left[\left(\frac{h / H T}{R H}\right) b_{1} \times b^{2}\left(1-\frac{h / H T}{R H}\right)\right] \times B T 1
$$

where BT is double bark thickness at any point above one tenth of the tree height, $\mathrm{h}$ the height where bark thickness to be estimated, HT the total tree height, RH the distance of the first tenth height from the top relative to HT, $b_{1}$ and $b_{2}$ are regression coefficients estimated from data, and BT1 is the double bark thickness at first tenth of height, which can be estimated with a very high precision from bark thickness at breast height. The DBTBH alone accounts for more than $80 \%$ of the variability in BT1.

Table 5 illustrates the standard error of estimates and bias at various positions along the bole for 9 species groups. The $S E_{E}$ ranges from $0.150 \mathrm{~cm}$ for maple to $1.508 \mathrm{~cm}$ for the Coastal mature Douglas-fir and the bias each tested position is less than $0.5 \mathrm{~cm}$. Therefore the bark taper equation is precise and accurate enough for practical applications.

\section{Summary}

Several equations have been studied in order to select the most practical one to predict bark volume with high precision and accuracy. Because of its simplicity and good predictive power, Equation [4], $V_{b}=a^{1} H^{b}{ }^{b} B^{c} H^{c} T^{d}$ is recommended for bark volume prediction. Bark taper equations, to estimate bark thickness at any given height above breast height, were also studied. Further research is presently underway to improve the findings of this study by providing better bark taper equations.

\section{References}

Blackman, T. 1978. Bark pellets are high-energy fuel for coal, gas application. For. Industries 105(2):18-19.

Brickell, J. E. 1970. Test of an equation for predicting bark thickness of western Montana species. USDA For. Serv. Res. Note Intermt. For. Range Exp. Sta. INT-107. 7 pp.

Demaerschalk, J. and A. Kozak. 1977. The whole-bole system: a conditioned dual-equation system for precise prediction of tree profiles. Can. Jour. For. Res. 7:488-497.

Dimitrov, E. T. 1976. Mathematical models for determining the bark volume of spruce in relation to certain mensurational characteristics. For. Abstract 37:6281.

Fedvccia, D.P. and W. F. Mann Jr. 1976. Bark thickness of 17-year-old loblolly pine planted at different spacings. US For. Serv. Res. Note Southern For. Exp. Sta. No. SO-210.

Hale, J. D. 1955. Thickness and density of bark trends of variation for six pulpwood species. Pulp \& Paper Magazine 56: (12):113-117.

Lange, R. W. 1971. Bark thickness, $k$ factors for four Montana coniferous tree species. Res. Note Montana Forest \& Conservation Exp. Stat. Missoula \#9. 2.pp.

MacKinney, A. L. 1934. Some factors affecting the bark thickness of second growth longleaf pine. J. For. 32:470-474.

Meyer, A. 1946. Bark volume determination in trees. J. For. 44:1067-1070.

Schneider, M. H. 1977. Energy from forest biomass. For. Chronicle. 63:215-218.

Smith, J. H. G. and A. Kozak. 1967. Thickness and percentage of bark of the commercial trees of British Columbia. Mimeo. Faculty of Forestry, UBC 33 pp.

1971. Thickness, moisture content, and specific gravity of inner and outer bark of some Pacific Northwest Trees. For. Products Jour. 21:38-40.

Stayton, C. L. and M. Hoffman. 1970. Estimating sugar maple bark thickness and volume. USDA For. Serv. Res. Pap. North Central For. Exp. Sta. NC-38. 7 pp. 